Abstracta Iranica Abstracta Iranica

Revue bibliographique pour le domaine irano-aryen

Volume 42-43 | 2021

Comptes rendus des publications de 2019-2020

\title{
Bruno De Nicola, "Pādshāh Khatun: An Example of Architectural, Religious, and Literary Patronage in Ilkhanid Iran"
}

\section{Simon Berger}

\section{(2) OpenEdition}

Journals

Édition électronique

URL : https://journals.openedition.org/abstractairanica/53819

DOI : 10.4000/abstractairanica.53819

ISSN : 1961-960X

Éditeur :

CNRS (UMR 7528 Mondes iraniens et indiens), Éditions de l'IFRI

\section{Référence électronique}

Simon Berger, "Bruno De Nicola, "Pādshāh Khatun: An Example of Architectural, Religious, and Literary Patronage in Ilkhanid Iran" », Abstracta Iranica [En ligne], Volume 42-43 | 2021, document 36 mis en ligne le 30 décembre 2021, consulté le 31 décembre 2022. URL : http://

journals.openedition.org/abstractairanica/53819; DOI : https://doi.org/10.4000/abstractairanica. 53819

Ce document a été généré automatiquement le 31 décembre 2022.

Tous droits réservés 


\title{
Bruno De Nicola, "Pādshāh Khatun: An Example of Architectural, Religious, and Literary Patronage in Ilkhanid Iran"
}

\author{
Simon Berger
}

\section{RÉFÉRENCE}

Bruno De Nicola. "Pādshāh Khatun: An Example of Architectural, Religious, and Literary Patronage in Ilkhanid Iran" in M. Biran, J. Brack, F. Fiaschetti (eds.). Along the Silk Roads in Mongol Eurasia: Generals, Merchants and Intellectuals. Oakland: University of California Press, 2020, p. 270-289.

L'article est consacré à la princesse qutlughkānide Pādshāh Khātūn, dirigeante de Kirmān sous suzeraineté mongole et épouses de deux ilkhan. L'A. revient d'abord sur les conditions de l'instauration de la dynastie qutlughkānide à Kirmān, et rappelle qu'elle était issue des Qara Khitai d'Asie centrale, parmi lesquels deux femmes furent impératrices de plein droit. Il retrace ensuite la vie et la carrière politique de Pādshāh Khātūn, qui fut très impliquée dans les affaires de l'ordo. Les dernières parties de l'étude insistent sur son mécénat à l'égard des religieux et des artistes, qui est replacé dans le double contexte de la tradition de patronage par les femmes de l'élite aussi bien dans le Moyen Orient musulman que dans le milieu turco-mongol, et sur sa propre production poétique. 


\section{AUTEURS}

SIMON BERGER

Doctorant EHESS, CETOBAC, Paris 